\title{
Controlled trial of a thymic hormone extract (Thymostimulin) in 'autoimmune' chronic active hepatitis
}

\author{
J E HEGARTY, K T NOURI ARIA, A L W F EDDLESTON, \\ AND ROGER WILLIAMS
}

From the Liver Unit, King's College Hospital and Medical School, Denmark Hill, London

SUMmARY A randomised controlled trial of thymic hormone extracts (Thymostimulin) (1 $\mathrm{mg} / \mathrm{kg} /$ day for seven days; $1 \mathrm{mg} / \mathrm{kg} /$ weekly thereafter) was undertaken in 30 patients ( 21 women, nine men) with treated, apparently inactive 'autoimmune' chronic active hepatitis during withdrawal of maintenance corticosteroid and azathioprine therapy. Reactivation of disease occurred in 26 patients ( $86 \%$ ) during or after treatment withdrawal and was as frequent in the Thymostimulin treated $(11$ of $13 ; 84 \%)$ and untreated $(15$ of $17 ; 88 \% ; \mathrm{p}>0.05)$ groups. Reactivation of disease was accompanied by a severe defect in concanavalin A induced suppressor cell activity, the magnitude of which was similar in the Thymostimulin treated and untreated groups (mean \% suppression $=16.4$ and 3.2 respectively; $p>0.05$ vs 84.4 in control subjects). Further studies assessing the optimal dose, duration of treatment, and mode of administration are required to establish a therapeutic role for thymic hormone extracts in 'autoimmune' chronic active hepatitis.

Chronic active hepatitis of unknown aetiology occurs predominantly in women, often with florid signs of hepatocellular failure, associated autoimmune disease, and marked derangement of liver function. Hyperglobulinaemia primarily involving an increase in immunoglobulin $G,{ }^{1}$ and the presence of specific ${ }^{2}$ and non-specific ${ }^{3}$ autoantibodies are the most striking immunological abnormalities and indicate a disturbance in the immunoregulatory mechanisms controlling antibody production. Antigen specific and non-specific suppressor $T$ lymphocytes are considered to play a major regulatory role in controlling B cell immunoglobulin production $^{45}$ and a defect in suppressor $\mathrm{T}$ cell function has been implicated in the pathogenesis of human ${ }^{67}$ and experimentally induced autoimmune disease ${ }^{8}$ including chronic active hepatitis. ${ }^{9}$

Several studies in vitro have shown that thymic hormone extracts stimulate human suppressor T cell activity $y^{10}$ and inhibit immunoglobulin production $^{12}{ }^{13}$ suggesting a possible role for their use in the treatment of autoimmune disease. The present

Address for correspondence: Dr Roger Williams FRCP, King's College Hospital Medical School, Denmark Hill, London SE5 8RX.

Received for publication 31 May 1983 study was designed to evaluate the effect of Thymostimulin (a calf thymic extract) in preventing clinical deterioration in a group of patients with autoimmune chronic active hepatitis, in apparently complete remission for prolonged periods, in whom conventional treatment was being withdrawn. Concurrent studies were performed to assess suppressor cell function in patients before and during treatment with Thymostimulin.

\section{Methods}

\section{PATIENTS}

Thirty patients (21 women, nine men, aged 20-69 years) satisfied internationally agreed criteria for chronic active hepatitis. ${ }^{14}$ The sera of all patients contained autoantibodies (smooth muscle and/or antinuclear factor) in titres greater than $1 / 40$ at some time during the course of their illness and all were negative for hepatitis $B$ surface antigen and antibody by radioimmunoassay (Ausria II and Ausab respectively, Abbott Laboratories, Basingstoke, UK). None had been exposed to known hepatotoxic drugs or transfused with blood or blood products. Duration of disease ranged from three to six years and remission from two to four years as 
defined by an absence of symptoms, serum aminotransferase (AST) concentrations within the normal range $(<40 \mathrm{IU} / 1)$ on at least four consecutive six monthly estimations, and liver histology showing mild portal lymphocytic infiltration in the absence of piecemeal necrosis. All patients were receiving prednisolone $(5-10 \mathrm{mg}$ ) and azathioprine (75-100 $\mathrm{mg}$ ) daily as maintenance treatment. In two patients on one previous occasion, withdrawal of treatment had resulted in biochemical relapse (AST $>240 \mathrm{IU} / \mathrm{l}$ ) of disease. The study was approved by the ethical committee of King's College Hospital and informed consent was obtained from all subjects.

Thymostimulin was kindly supplied by Serono Laboratories (UK) Ltd, Welwyn Garden City, Herts. The method of extraction and purification has been previously described. ${ }^{15}$ Briefly, ammonium acetate extraction of minced calf thymuses is followed by two precipitation steps with ammonium sulphate. The precipitate from the second step is subjected to ultrafiltration and then purified on Sepharose G25 and G50. The resulting extract contains a mixture of polypeptides with molecular weights lower than 12000 , with two main bands on polyacrylamide gel electrophoresis. Standardisation of the activity of the extract is performed by comparing it with a standard preparation of Thymostimulin in a bioassay using induction of rosette forming cells in guinea pig spleen preparations. ${ }^{16}$

The patients were randomised to receive intramuscular Thymostimulin $1 \mathrm{mg} / \mathrm{kg} / \mathrm{day}$ for one week, and $1 \mathrm{mg} / \mathrm{kg} /$ week thereafter (13 patients), or no therapy (17 patients) at the beginning of treatment withdrawal. Azathioprine was discontinued and prednisolone simultaneously reduced by $2 \mathrm{mg}$ and by a further $2 \mathrm{mg}$ at two weekly intervals. Serum concentrations of AST, bilirubin, alkaline phosphatase, immunoglobulins, and autoantibody titres were monitored at two weekly intervals. A fourfold rise of AST ( $>160 \mathrm{IU} / \mathrm{l})$ was taken to indicate reactivation of disease and if this occurred, Thymostimulin was discontinued and treatment recommenced with prednisolone $(30 \mathrm{mg})$ and azathioprine $(75 \mathrm{mg})$.

SUPPRESSOR CELL ASSAY

The assay used to examine suppressor $T$ cell function has been previously described ${ }^{9}$ and is based on the ability of concanavalin A (con A) stimulated suppressor cells to inhibit B cell proliferation and immunoglobulin production. Briefly, peripheral blood lymphocytes were isolated ${ }^{9}$ and cultured with pokeweed mitogen, a B cell stimulant, in the presence or absence of con A, for seven days in an atmosphere of $5 \% \mathrm{CO}_{2}$ in air. The number of stimulated B cells secreting immunoglobulin G
(IgG) in the presence and absence of con A activated suppressor cells was then determined by means of haemolytic plaque assay. In this assay secreted immunoglobulins bind to staphylococcus protein A coated sheep red blood cells. When anti-IgG and complement are added lysis of the red cells occurs, producing clear areas in an agar gel around each immunoglobulin secreting cell. Each study was performed in duplicate and the number of haemolytic plaques reported per $10^{6}$ viable cells as assessed by trypan blue exclusion. The results are expressed as \% suppression (suppression index) based on the ratio of the number of immunoglobulin secreting cells in the presence and absence of con A activated suppressor cells. The following formula was used:

\% suppression

(suppression index)

$$
=1-\left[\begin{array}{c}
\begin{array}{c}
\text { No of IgG producing cells } \\
\text { (pokeweed mitogen }+ \text { con } A)
\end{array} \\
\begin{array}{c}
\text { No of IgG producing cells } \\
\text { (pokeweed mitogén) }
\end{array}
\end{array}\right] \times 100
$$

Results

Clinical (Fig. 1)

Reactivation of disease occurred in 11 out of 13 Thymostimulin treated patients $(84 \%)$ compared with 14 out of $17(82 \%)$ of patients receiving no therapy ( $>0.05, \chi^{2}$ analysis) (Fig. 1) and was confirmed histologically by the presence of piecemeal necrosis in all 13 patients (seven Thymostimulin treated; six untreated) where liver biopsy was performed. The mean interval between withdrawal of treatment and reactivation of disease was similar in the Thymostimulin and untreated

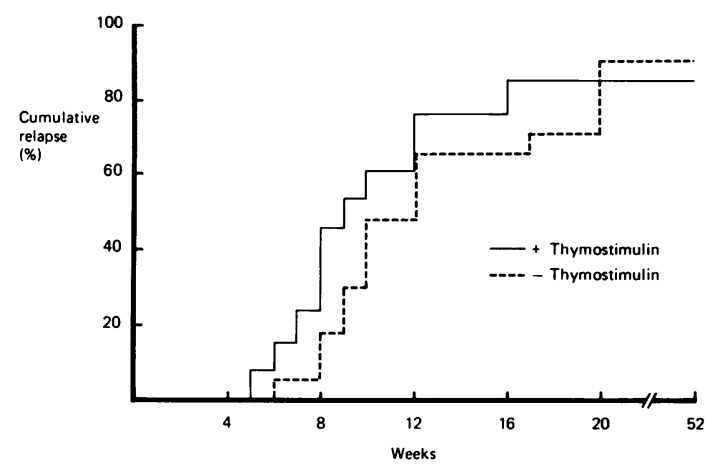

Fig. 1 Chronic active hepatitis. Percentage of patients with relapse of disease following treatment withdrawal. ( - ) and (..-_) represent percentage relapse in patients who did and did not receive Thymostimulin. 
groups (9.3 and 11.2 weeks respectively) as was the mean increase in AST (581 and $600 \mathrm{U} / \mathrm{l}$ ) and rise of serum IgG $(20.1$ and $20.5 \mathrm{~g} / \mathrm{l})$. Changes in serum autoantibody titres or the reappearance of autoantibodies in patients who had become autuantibody negative on corticosteroid treatment was similar in the two groups.

\section{SUPPRESSOR CELL FUNCTION (FIg. 2)}

Suppressor cell function was studied before treatment withdrawal in 15 patients with inactive disease maintained on prednisolone and azathioprine and in the same group of patients after reactivation of disease. Seven of these patients received Thymostimulin from the start of treatment withdrawal. Twenty normal laboratory volunteers (aged 19-63 years) served as controls. Before withdrawal of treatment the suppression index in the patients with inactive disease (78.3 \pm SD 10.8) was similar to control values $(84.4 \pm$ SD $10.4 \mathrm{p}>0.05$; Wilcoxon's rank sum test) and did not differ between those patients who did (79.6 \pm SD 13.1) and did not (77.6 \pm SD 18.9) receive Thymostimulin. A defect in suppressor cell function accompanied reactivation of disease in all patients studied, the magnitude of which was similar in the Thymostimulin treated $(16.4 \pm$ SD 38.2) and untreated (3.2 \pm SD 32.4 $\mathrm{p}>0.05)$ groups.

\section{Discussion}

Thymic hormone extracts induce differentiation of murine and human thymus dependent $\mathrm{T}$ lympho-

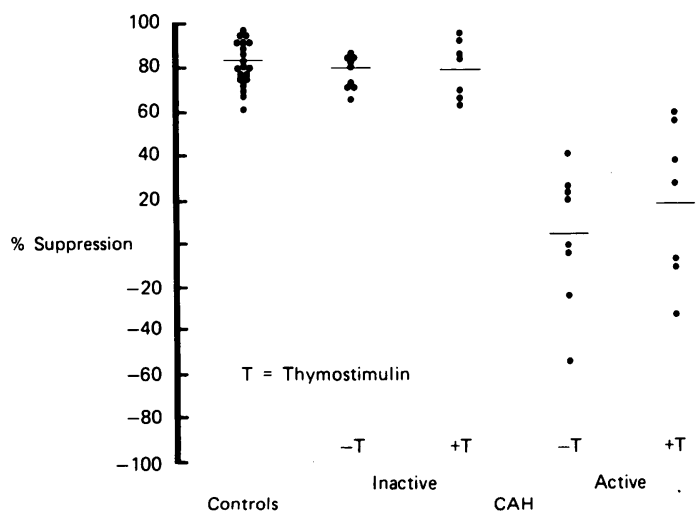

Fig. 2 Suppressor cell activity in normal subjects and in patients with chronic active hepatitis in remission and in the same patients with relapse of disease. $(+)$ and $(-)$ indicates suppressor cell activity in patients who did and did not receive Thymostimulin $(T)$. Horizontal bars represent mean values. cytes as assessed by expression of specific surface markers, formation of spontaneous erythrocyte rosettes, graft $v s$ host reactivity and sensitivity to $\mathrm{T}$ cell specific antisera, azathioprine, or hydrocortisone.$^{10}$ In addition, thymic extracts have been shown to inhibit the proliferative response of normal human lymphocytes to mitogens ${ }^{13}$ and to reverse a suppressor cell defect in systemic lupus erythematosus, ${ }^{11}$ by mediating the differentiation of precursor $\mathrm{T}$ cells to functional suppressor cells. The potential therapeutic importance of these in vitro observations has been emphasised by the results of studies in which administration of thymic extracts has abolished immunoregulatory abnormalities and induced clinical remission in patients with histiocytosis $\mathrm{X}^{17}$ (a disease characterised by defective suppressor $T$ cell function) and other immune deficiency states. ${ }^{18-21}$ These data suggested that thymic extracts might also be of benefit in autoimmune chronic active hepatitis, a disease in which defective suppressor $\mathrm{T}$ cell function is thought to play a major pathogenic role.

The present study confirms previous observations that reactivation of disease $e^{22}$ accompanied by a defect in suppressor cell function ${ }^{9}$ occurs in the majority of patients with autoimmune chronic active hepatitis when maintenance corticosteroid treatment is withdrawn. Thymostimulin, at the dose used, had no effect on the clinical course or on the appearance of the suppressor cell abnormality during treatment withdrawal. Reactivation of disease occurred as often in the Thymostimulin treated and untreated groups and was invariably accompanied by a defect in suppressor cell function, the magnitude of which was similar in the two groups. There are a number of possible explanations for this apparent lack of an effect of Thymostimulin in this study. Many of the in vitro studies showing an immunomodulatory effect of thymic extracts used a concentration which would far exceed the anticipated plasma levels in patients receiving the regime used in the present study. This problem should be at least partially resolved with the recent development of a sensitive immunoassay for serum thymic hormone levels ${ }^{23}$ which may allow evaluation of the immunological effects of Thymostimulin at comparable concentrations in vivo and in vitro. Previous studies ${ }^{182021}$ had shown that, in some patients, there was a latent period of up to six months between initial administration of Thymostimulin and maximal improvement in $T$ cell maturation and parameters of delayed hypersensitivity. If indeed a prolonged period of treatment is required to produce an immunological response, the lack of an effect of Thymostimulin in the present study may be because the duration of 
treatment was not long enough to allow maturation of immunocompetent suppressor $\mathrm{T}$ cells.

Thymic extracts have been shown in vitro to stimulate both helper and suppressor $\mathrm{T}$ cell activity in an unpredictable fashion. ${ }^{24}$ As the suppressor cell assay used in the present study measures the net effect of suppressor and helper $T$ cells on $B$ cell immunoglobulin production, it is not possible to categorically state that Thymostimulin is not stimulating suppressor cells as simultaneous stimulation of helper $T$ cells would result in an apparent lack of effect on suppressor cells. Stimulation of both suppressor and helper cells by thymic extracts may have important clinical implications. The autoimmune process in chronic active hepatitis may be primarily due to defective suppressor cell function resulting in uncontrolled proliferation of $B$ cells which produce tissue damaging autoantibodies. In these circumstances preferential stimulation of helper $T$ cells could theoretically aggravate rather than ameliorate the immunological abnormalities and produce clinical deterioration.

These results represent the first controlled study on the effect of long term parenteral administration of a thymic hormone extract in a well defined, homogenous, carefully monitored patient population. The lack of a demonstrable clinical and immunological effect contrasts with the results of previous in vivo and in vitro studies suggesting that further evaluation is required to assess the effect of different dose schedules, and modes of administration of thymic extracts in patients with chronic active hepatitis.

\section{References}

1 Feizi T. Immunoglobulins in chronic liver disease. Gut 1968; 9: 193-8.

2 Jensen DM, McFarlane IG, Portmann B, Eddlestone ALWF, Williams R. Detection of antibodies directed against a liver specific membrane lipoprotein in patients with acute and chronic active hepatitis. $N$ Engl $J$ Med 1978; 299: 1-7.

3 Doniach D, Roitt IM, Walker JG, Sherlock S. Tissue antibodies in primary biliary cirrhosis, active chronic lupoid hepatitis, cryptogenic cirrhosis and other liver diseases and their clinical implications. Clin Exp Immunol 1966; 1: 237-62.

4 Fauci AS. Immunoregulation in autoimmunity. $J$ Allergy Clin Immunol 1980; 66: 5-17.

5 Reinherz EL, Schlossman SF. Current concepts in immunology. Regulation of the immune response inducer and suppressor $\mathrm{T}$ lymphocyte subsets in human beings. $N$ England J Med 1980; 303: 370-3.

6 Bresnihan B, Jasin HE. Suppressor function of peripheral blood lymphocytes in normal individuals and in patients with systemic lupus erythematosus. $J$ Clin Invest 1977; 59: 106-16.

7 Hardin JA, Chused JM, Steinberg AD. Suppressor cells in the graft vs. host reaction. J Immunol 1973; 3: 650-1.

8 Talal N, Dauphinee M, Pillarisetty R, Goldblum R. Effect of Thymosin on thymocyte proliferation and autoimmunity in NZB mice. Ann NY Acad Sci 1975 249: 438-50.

9 Nouri Aria KT, Hegarty JE, Alexander GJ, Eddleston ALWF, Williams R. Effect of corticosteroids on suppressor cell activity in autoimmune and viral chronic active hepatitis. $N$ Engl J Med 1982; 307: 1301-4.

10 Wolf RE. Thymosin induced suppression of proliferative response of human lymphocytes to mitogens. J Clin Invest 1979; 63: 677-83.

11 Horowitz S, Bircherding W, Moorthy AV, Chesney R, Schutte-Wissermann II, Hong $R$. Induction of suppressor $\mathrm{T}$ cells in systemic lupus erythematosus by thymosin and cultured thymic epithelium. Science 1977; 197: 999.

12 Wara D, Goldstein AL, Doyle NE, Amman AJ. Thymosin activity in patients with cellular immunodeficiency. $N$ Engl J Med 1975; 292: 70-4.

13 Wolf RE, Goldstein AL, Ziff M. Suppression by Thymosin of pokeweed mitogen induced differentiation of human B cells. Clin Immunol Immunopathol 1978; 11: 303-6.

14 Leevy CM, Popper H, Sherlock S. Diseases of the liver and biliary tract. Standardisation of nomenclature, diagnostic criteria and diagnostic methodology. US Government Printing Office, Washington, DC: Proceedings No. 22, DHEW Publication No. (NIH) 76-725, p. 212. 1978.

15 Falchetti R, Bergesi G, Eshkol A et al. Pharmacological and biological properties of a calf thymus extract (TP-1). Drugs Exp Clin Res 1977; 3: 39.

16 Fulchetti R, Cafiero C, Caprino L. Bioassay for thymic extracts: guinea pig spleen lymphocytes - rabbit red blood cells rosette method. Cancer Biochem Biophys 1979; 4: 69.

17 Osband ME, Lipton JM, Lavin P et al. Histiocytosis X, demonstration of abnormal immunity, $\mathrm{T}$ cell histamine $\mathrm{H}_{2}$-receptor deficiency, and successful treatment with thymic extract. $N$ Engl J Med 1981; 304: 146-53.

18 Aiuti F, Ammirati P, Fiorilli $\mathrm{M}$ et al. Immunologic and clinical investigation on a bovine thymic extract. Therapeutic applications in primary immunodeficiency. Pediatr Res 1979; 13: 797-802.

19 Bordigoni P, Faure G, Bene MC et al. Improvement of cellular immunity and $\operatorname{IgA}$ production in immunodeficient children after treatment with synthetic serum thymic factor (FTS). Lancet 1982; 2: 293-7.

20 Davis EF, Levinsky RJ. Treatment of cell mediated immunodeficiency with calf thymic hormone (TPI). Pediatr Res 1982; 16: 573-8.

21 Shoham J, Theodor E, Brenner HJ, Goldman B, Lusky A, Chaitchick S. Enhancement of the immune system of chemotherapy treated cancer patients by simultaneous treatment with thymic extract, TP-1. Cancer Immunol Immunother 1980; 9: 173-80.

22 Hegarty JE, Nouri Aria KT, Eddleston ALWF, 
Portmann B, Williams R. Relapse following treatment withdrawal in patients with autoimmune chronic active hepatitis. Hepatology 1983; 3: 685-9.

23 Lisi PJ, Teipel JW, Goldstein G, Schiffman H. Improved radioimmunoassay technique for measuring serum thymopoietin. Clin Chim Act 1980; 107: 111-9.

24 Kaufman DB. Maturational effects of thymic hormones on human helper and suppressor T cells: effect of FTS (Facteur Thymique Serigue) and Thymosin. Clin Exp Immunol 1980; 39: 722-7. 